\title{
Mitos, ritos e símbolos: o culto a Nossa Senhora das Águas-PR
}

\author{
Myths, rites and symbols: the cult of Nossa Senhora das Águas-PR
}

\author{
João Paulo Pacheco Rodrigues* \\ Sandra de Cássia Araújo Pelegrini**
}

\begin{abstract}
Resumo
Esse artigo propõe analisar a festa de Nossa Senhora das Águas-PR, a partir dos anseios da comunidade católica de Ivatuba. Mesmo que essa celebração seja uma prática religiosa que se fundamenta em ritos e símbolos de outros lugares, apresenta, contudo, particularidades que foram solidificadas no processo de criação da santa na região onde serpenteia o rio Ivaí. Pautados nos pressupostos teóricos de Burke (2004), Hobsbawm (1984) e Portelli (2004), buscamos compreender as raízes para tal devoção e como o sentimento mariano foi solidificado no cerne ivatubense.
\end{abstract}

Palavras-chave: História regional; Patrimônio imaterial; Catolicismo popular.

\begin{abstract}
This article proposes to analyze the feast of Nossa Senhora das Águas-PR, from the perspective of the universe of Popular Catholicism. Even though this celebration is a religious practice based on rites and symbols from other places, it presents, however, particularities that were solidified in the process of creating the saint in the region where the river Ivaí meanders. Based on the theoretical assumptions of Burke (2004), Hobsbawm (1984) and Portelli (2004), we sought to understand the roots of such devotion and how the Marian sentiment was solidified in the heart of the city.
\end{abstract}

Keywords: Regional history; Intangible heritage; Popular Catholicism.

No início da década de 2010, na fase embrionária dessa pesquisa, foi realizada uma série de entrevistas com alguns moradores de Ivatuba ${ }^{1}$. O contato direto com a população residente tornou possível a percepção de valores que integravam a construção do mundo social dessas pessoas, entre eles, o seu conjunto de crenças.

\footnotetext{
* Doutorando em História pela Universidade Estadual de Maringá (UEM). Professor Tutor do curso de História modalidade EAD/UAB da Universidade Estadual de Maringá (UEM). Pesquisador do Centro de Estudos das Artes e do Patrimônio Cultural (CEAPAC). Email: joaopacheco2210@ hotmail.com.

** Doutora em História Social pela Universidade de São Paulo (USP). Pós-Doutora em Patrimônio Cultural pela Universidade Estadual de Campinas (UNICAMP). Professora do Programa de Pósgraduação em História da Universidade Estadual de Maringá (UEM). Coordenadora do Museu Bacia do Paraná (MBP) e do Centro de Estudos das Artes e do Patrimônio Cultural (CEAPAC). Email: sandrapelegrini@yahoo.com.
}

Recebido em dezembro de 2016 | Aprovado em junho de 2017.

${ }^{1}$ Ivatuba está localizada na região norte do Paraná, a $450 \mathrm{~km}$ da capital Curitiba. 
Dentre as lembranças reveladas pelas entrevistas, fenômenos ligados a festa de Nossa Senhora das Águas foram predominantemente mencionados por um ou outro motivo, sinalizando as dádivas e contradádivas recebidas como marco nas trajetórias existenciais dos depoentes. A celebração acontece anualmente, desde o início do século XXI, na região norte do Paraná, e reúne valores e práticas relacionadas ao catolicismo popular como a devoção, a piedade e o compromisso com a santa e a sociedade na qual ela foi criada. , pois simbolizam a crença de segmentos sociais distintos. Nesse artigo, procura-se, por um lado, apreender o mito fundador da Virgem do Ivaí e, por outro, entender esse fenômeno religioso como uma representação dos anseios da comunidade unida em torno da fé.

A festa de Nossa Senhora das Águas, embora seja uma prática que se baseia em crenças e cultos semelhantes à de outros locais, apresenta, particularidades que foram solidificadas no processo de criação da santa na região onde serpenteia o rio Ivaí. Segundo Destefani (2005), a bacia hidrográfica do rio Ivaí é a segunda maior do Estado do Paraná. Com uma área de $36.587 \mathrm{~km}^{2}$ e um percurso de $680 \mathrm{~km}$, o rio é afluente da margem esquerda do curso superior do rio Paraná e apresenta uma vazão média de 363 $\mathrm{m}^{3}$.

O Ivaí nasce em Prudentópolis, na região Centro-Sul do Estado do Paraná, no encontro entre os rios dos Patos e São João. Uma de suas características refere-se à tonalidade das suas águas, que na maior parte do ano é vermelha ou marrom. Quando o rio deságua nas águas do rio Paraná, ocorre o fenômeno de instabilidade hidrodinâmica, também conhecido como encontro das águas.

Cabe lembrar que este rio, o mais representativo para região, tem grande importância - para a população rural como para as cidades que o cercam, tanto pela territorialidade que seu recorte faz, como pela captação de água. O Ivaí está presente nas reminiscências de antigos moradores que retém viva em suas memórias as pescarias que até hoje fazem parte do cotidiano ivatubense.

Segundo os historiadores Pelegrini e Rodrigues (2014) na obra "Ivatuba: História, memória e tradição paranaense" a fundação de Ivatuba está vinculada ao processo de reocupação ${ }^{2}$ do Norte do Paraná. Essa região, conforme apontam

\footnotetext{
${ }^{2}$ O termo reocupação é designado ao processo de ocupação moderna o da região norte do estado do Paraná pela Companhia de Melhoramentos do Norte do Paraná, uma vez que existem evidencias que compravam que o local fora habitado por populações indígenas.
} 
consistentes pesquisas sobre o tema, era local de ocupação humana há muito tempo ${ }^{3}$. No entanto, apenas nos anos trinta do século XX, essa região passou por um intenso processo de parcelamento, pela comercialização e ocupação capitalista do solo, de modo ofensivo. A partir desta década, a atuação de companhias de colonização, entre elas a Companhia de Terras Norte do Paraná (CTNP), que deu origem a Companhia Melhoramentos Norte do Paraná (CMNP) deu vazão a acelerada reocupação por meio da plantação de extensos cafezais, do desmatamento que deu lugar às ferrovias, rodovias e fundação de inúmeras cidades circunvizinha a Maringá.

O efetivo loteamento da cidade de Ivatuba ocorreu após a aquisição da faixa de terras próxima ao Rio Ivaí por parte da empresa Pareja e Cia Ltda., comercializada pela referida companhia no começo da década de 1950 (PELEGRINI; RODRIGUES, 2014).

\section{Desvelando o mito: o que a história oficial não contou}

Segundo Olinto Presa ${ }^{4}$, os primeiros moradores de Ivatuba escolheram como protetor São Sebastião, em decorrência dele ser padroeiro de cidades catarinenses como, por exemplo, o Bom Retiro, de onde migraram parte dos moradores do município. Outro fator que teria influenciado a escolha desse santo devia-se ao fato que dele teria sido um soldado romano, aspecto que "conquistava a empatia dos moradores". Vale destacar a popularidade do padroeiro também representado na literatura, no livro "Fabíola", do Cardeal Nicholas Wiseman e no cinema, pelos filmes "A revolta dos Escravos" e "Fabíola" adaptado da obra homônima.

Segundo Saul Dandolini, nos meses de janeiro eram realizadas procissões e festas em louvor a São Sebastião por iniciativa dos catarinenses e dos paulistas, como se pode observar na fotografia que segue:

\footnotetext{
${ }^{3}$ Para o historiador Lucio Tadeu Mota (2005), o lugar era habitado por populações indígenas há cerca de 8 mil anos, podendo mesmo chegar a 13 mil anos. Conforme apontam estes mesmos estudos, é importante dizer que não há uma continuidade étnica e cultural entre os ivatubenses e as populações pré-históricas e indígenas que viveram onde atualmente se encontram os limites do rio Ivaí. Para "existir o Norte do Paraná, foi necessário expulsar, destruir e confinar as populações indígenas que viviam nessas regiões." (MOTA, 1999, p. 6).

${ }^{4}$ Olinto Presa. Entrevistado por João Paulo Pacheco Rodrigues, 18 maio 2010.
} 


\section{Imagem 1 - Festa de São Sebastião em Ivatuba}

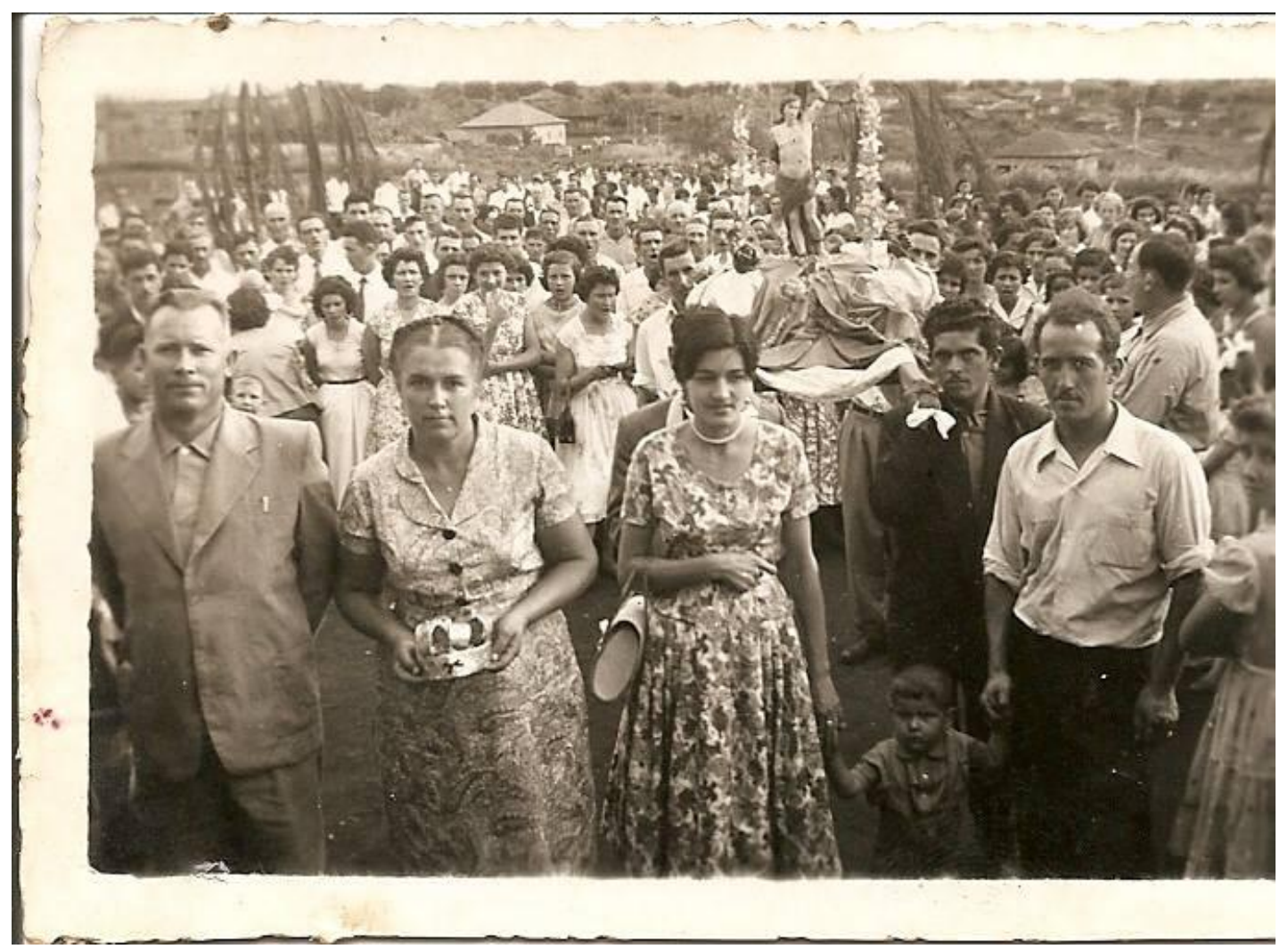

Fonte: Acervo João Fabre, 1949.

Nesse registro, o fotógrafo colocou em evidência um ângulo mais restrito da procissão, por meio do qual é possível observar a paisagem e o aglomerado de pessoas em procissão. Ao centro e na parte superior é possível notar também a imagem de São Sebastião, carregado sob um andor. A foto data de 1949 e conforme o relato do senhor Saul Dandolini, a festa era realizada sempre na última semana do mês de janeiro,

É preciso considerar que o documento imagético não é neutro: a fotografia traz consigo um discurso que deve ser visto e revisto dentro do contexto no qual ela foi produzida, pois, como aponta Burke (2004), as imagens interessam ao historiador, tanto pelo que deixam transparecer, quanto pelo que omitem. Nesse caso, o autor do disparo ao enquadrar os participantes da procissão em perspectiva, ocasionou a sensação de que o evento estava com número elevado de pessoas.

A imagem revela outro aspecto que atesta a importância da celebração religiosa: os participantes estão bem trajados, provavelmente com suas roupas sociais utilizadas em ocasiões especiais. Os homens de terno, camisas de manga longa com ou sem 
gravata e as mulheres trajando vestidos floridos, bolsas, colares, brincos e cabelos longos presos mostravam-se de maneira respeitosa e antenadas aos modismo da época.

No entanto, embora o referido santo tivesse despertado o sentimento de devoção por parte significativa da população, a paróquia foi oficialmente consagrada por Dom Jaime Luiz Coelho à Nossa Senhora do Rocio, em 31 de maio de 1965. Para o agricultor e morador de Ivatuba, João Fabre, o arcebispo alegou que essa escolha foi justificava pelo fato da imagem de Nossa Senhor do Rocio ter sido encontrada por pescadores em Paranaguá, e como a pesca era uma atividade recorrente em Ivatuba, o religioso "achou por certo escolher essa padroeira, mesmo que a população já tivesse escolhido outro padroeiro" ". Embora relutantes, a aquiescência dos fiéis em relação a patrona se deu em uma circunstância especial, qual seja, houve uma barganha velada em nome da elevação daquela capela a condição de paróquia, graças a institucionalização concedida por Dom Jaime Luiz Coelho.

Ainda que as famílias migradas dos estados de Santa Catarina e São Paulo para a região, entre as décadas de 1940 a 1960, se unissem nos momentos de celebração religiosa, no âmbito político, tais correntes migratórias tornaram-se rivais, protagonistas das três primeiras eleições em Ivatuba. No panfleto partidário (Imagem 2), pode-se constatar a rivalidade entre essas duas comunidades:

\section{Imagem 2 - Panfleto do candidato Daniel Sapata}

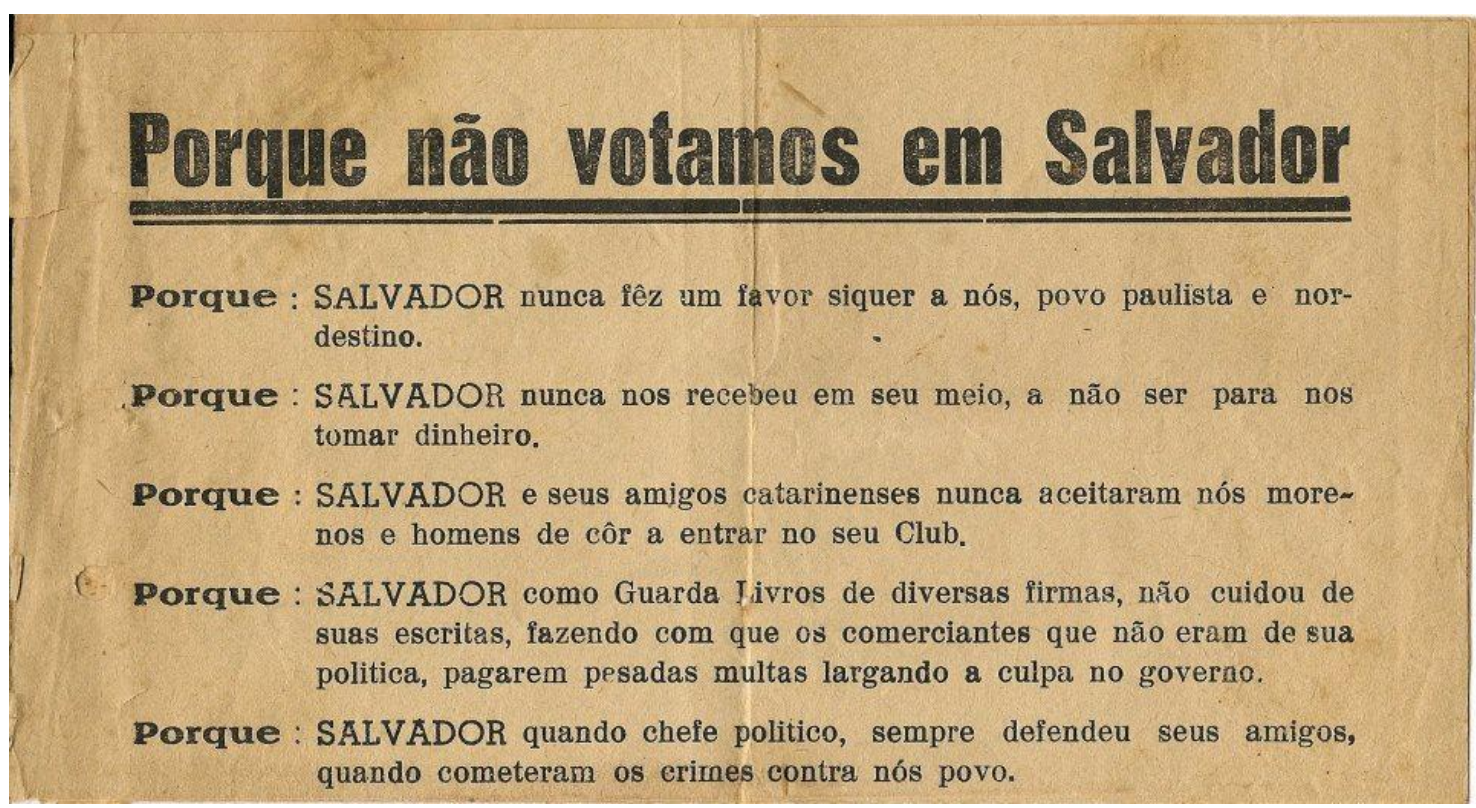

Fonte: Acervo família Salvador. 1965

\footnotetext{
${ }^{5}$ João Fabre. Entrevistado por João Paulo Pacheco Rodrigues, 8 fev. 2012.
} 
No panfleto distribuído em Ivatuba, na semana que antecedeu a eleição para chefe do executivo municipal, nota-se certa hostilidade catarinenses e paulistas, principalmente nos primeiros dizeres: "SALVADOR nunca fez favor [...] a nós povo paulista e nordestino". A conturbada relação entre paulistas e catarinenses também é evidenciada na frase: "SALVADOR ${ }^{6}$ e seus amigos catarinenses nunca aceitaram nós, morenos e homens de cor [...] no seu Club", ou seja, no Porto de Areia, local de encontro entre os catarinenses, atualmente reconhecido como Condomínio Pontal do Ivaí.

Foi durante essa corrida eleitoral que a comunidade católica de Ivatuba presenciou um fato inusitado, segundo relatos de antigos moradores ${ }^{7}$. Em uma Celebração Eucarística, o pároco do município teria feito a premonição de que a cidade nunca se desenvolveria para o sentido Sul. O responsável por tal premonição era o padre paulista Pedro Jarussi, amigo próximo de Daniel Sapata, candidato que representava as famílias paulistas, por conseguinte, um oponente natural do político catarinense Salvador. E mais, exatamente no lado sul de Ivatuba, região que Jarussi teria afirmado jamais se desenvolveria, morava Silvestre Salvador, candidato da ala catarinense.

Nos depoimentos orais levantados durante a pesquisa detectamos que, embora o pároco tenha tratado o assunto como uma premonição, a fala dele acabou contribuído para a vitória de Daniel Sapata e, consequentemente, colaborou para a estagnação da região sul, uma vez que durante o mandato de Sapata a área recebeu poucos investimentos. Entre os habitantes, essa história adquiriu grande repercussão e acabou sendo interpretada como uma maldição do padre. O imaginário popular ivatubense atravessou décadas sustentado nas conversas informais, nos velórios, nas missas, cultos e novenas católicas.

Cumpre lembrar, que entre as fontes levantadas nesse estudo (documentações oficiais como folhetos e revistas comemorativos), não foram encontradas indícios de registros que narrassem as passagens da premonição do padre Pedro Jarussi, da devoção a São Sebastião e a rivalidade política entre catarinenses e paulistas. Só foi possível encontrar essas eminencias, graças aos depoimentos dos primeiros moradores e da comunidade católica da região.

\footnotetext{
${ }^{6}$ Silvestre Salvador, natural de Nova Veneza-SC, foi vereador na gestão de Vander Ribeiro (1961-1965) e junto com os Srs. Augusto Grasso, José Bendo, Francisco Baggio, João Fabre e Otávio Perin construíram o prédio do Hospital Municipal.

${ }^{7}$ Maria Presa. Entrevistado por João Paulo Pacheco Rodrigues, 2 ago. 2008. A Sr. ${ }^{a}$ Maria Presa à época ministra da Eucaristia nas celebrações.
} 
O cotejamento de fontes plurais, entre elas as memórias e narrativas dos antigos moradores da cidade, permitiu apreender valiosas pistas sobre formação da comunidade católica em Ivatuba. Jacques Le Goff (2003) assevera que esses resquícios estabelecem um "vínculo entre as gerações humanas e o tempo histórico que as acompanha", fazendo um paralelo entre a "memória individual e coletiva". Ela é "mítica, deformada e anacrônica". Mítica, pois ela pode ser inventada de uma coisa que não existiu; deformada porque muitas vezes ela pode omitir ou aumentar algum aspecto; e anacrônica por não se utilizar o tempo, como uma cronologia, as lembranças simplesmente vem à tona. As memórias preservadas estão relacionadas às tradições e aos valores culturais que unem os grupos que possuem identidades e interesses em comum. Logo, foi crucial ter tomado as memórias nesse estudo como uma fonte explorada pela história.

Sobre a maldição do padre, Anísio Furlan recorda que a história ganhou contornos emotivos e palpáveis no final da década de 1970, quando um grave acidente ocorreu as margens do rio Ivaí. Uma senhora, cujo nome o agrônomo não recorda, se afogou e veio a falecer horas depois. Com isso, o Sr José Bendo, proprietário do sítio que posteriormente seria o condomínio Pontal do Ivaí, passou a proibir as visitas naquele local.

Na mesma década outro fato chamou a atenção de Furlan, seu primo Sibério Bendo, encontrou, nas proximidades do Ivaí, uma imagem de Nossa Senhora. No entanto, esta figura não tinha sua extremidade superior, fato que o próprio síndico do condomínio ressaltou como o primeiro indicativo da necessidade de arquitetar alguma menção divina, relacionada a figura de Maria com o pontal do Ivaí. Anísio lembra que esta estatua foi entregue ao padre Pedro Watar Makiyama da Paróquia Nossa Senhora do Rocio, o mesmo a guardou em seu acervo.

No final da década de 1980, o agricultor Anísio Furlan herdou de seu avô José Bendo, uma faixa de terra próxima ao rio Ivaí, a mesma apontada como "amaldiçoada" pelo padre Pedro Jarussi, e passou a se dedicar a construção de um empreendimento imobiliário que utilizasse o rio Ivaí como chamariz. No ano de 1997, iniciou-se o projeto que no futuro receberia o nome de "Condomínio Pontal do Ivaí".

Com uma intensa propaganda fundamentada no ideário de lazer, diversão e meio ambiente, os primeiros lotes foram vendidos num rápido espaço de tempo. Porém 
Anísio Furlan ${ }^{8}$ e os responsáveis pelo condomínio Pontal do Ivaí encontraram um grande problema que inviabilizaria toda comercialização dos lotes do condomínio: a falta de água para abastecer a região.

Segundo o dono do loteamento, diversos especialistas, como geólogos, analisaram as condições do condomínio com a intenção de localizar um lugar que pudessem servir como poço artesiano. Preocupados com o problema, os responsáveis pelo loteamento solicitaram que o Padre Jair Favoretto, que havia adquirido um lote de terras, realizasse uma celebração em louvor a Nossa Senhora, para que esta intercedesse pelos condôminos em busca da água.

O Padre aceitou o pedido e ministrou uma missa pedindo a intervenção da Virgem Maria. Após alguns dias, em nova tentativa, a empresa ao perfurar uma abertura de quinze metros encontrou água potável. Assim, puderam retomar o processo de comercialização das datas do terreno.

Em dezembro 2001, após o término das obras de infraestrutura, o Padre Jair Favoretto $^{9}$, procurou Furlan, com a intenção de realizar uma festa similar à de Nossa Senhora dos Navegantes, numa forma de potencializar o turismo na região e de ecoar aos fiéis a importância da preservação ao meio ambiente e os cuidados com o rio Ivaí.

No entanto, ambos rejeitaram a ideia da celebração ser em louvor a Nossa Senhora dos Navegantes, pois essa festa acontecia em diversos lugares do Brasil, como na cidade de Porto Alegre, no Rio Grande do Sul, e no Paraná, na cidade de Paranaguá ${ }^{10}$

Segundo Padre Jair Favoretto ${ }^{11}$, foi realizada uma série de reuniões com a comissão organizadora do loteamento, para a escolha do nome da festa e criação da alcunha da Santa que passaria a ser a padroeira do condomínio. Decidiram então, pelo título de Nossa Senhora das Águas. A celebração iria acontecer às margens do rio Ivaí, como forma de agradecimento à Virgem Maria pela graça alcançada, no caso o acesso à

\footnotetext{
${ }^{8}$ Anísio Furlan. Entrevistado por João Paulo Pacheco Rodrigues, 30 abr. 2009.

${ }^{9}$ Pe. Jair Favoretto. Entrevistado por João Paulo Pacheco Rodrigues, 21 maio 2009.

${ }^{10}$ Paranaguá é um município localizado no litoral do Paraná, considerada a cidade mais antiga do Estado. Segundo dados do IBGE, em 2010 possuía 140.469 habitantes.

${ }^{11}$ Cumpre lembrarmos que ao explorarmos os depoimentos como fonte desse estudo, torna-se vital compreendermos sob a ótica de Portelli (2004) que essas fontes seguem uma linha tênue com tempo, na qual crescem e se decompõem, por isso é essencial desenvolver artifícios que preservem esses relatos e as diversas memórias das populações. No caso desse estudo, as entrevistas foram gravadas e transcritas na sua forma original, observando o contexto histórico em que elas foram narradas
} 
água potável, ainda no processo de comercialização dos lotes. E também, pelo tema da Campanha da Fraternidade ${ }^{12}$ daquele ano que versava "Água fonte de vida".

\section{Marianismo em perspectiva: a figura de Nossa Senhora das Águas}

Favoretto viajou para cidade de Aparecida do Norte, centro do catolicismo no Brasil, e contratou um artesão especializado na confecção de santos. O pároco lembra que uma das primeiras observações que o mesmo pediu ao artista era que fizesse uma estátua com traços "serenos" e com cores claras. Exigiu também que a Santa fugisse do estereótipo da imagem de Nossa Senhora dos Navegantes e de Iemanjá, que na opinião do pároco era "muito poluída e cheia de traços".

\section{Imagem 3 - Adesivo comemorativo da Festa de Nossa Senhora das Águas}

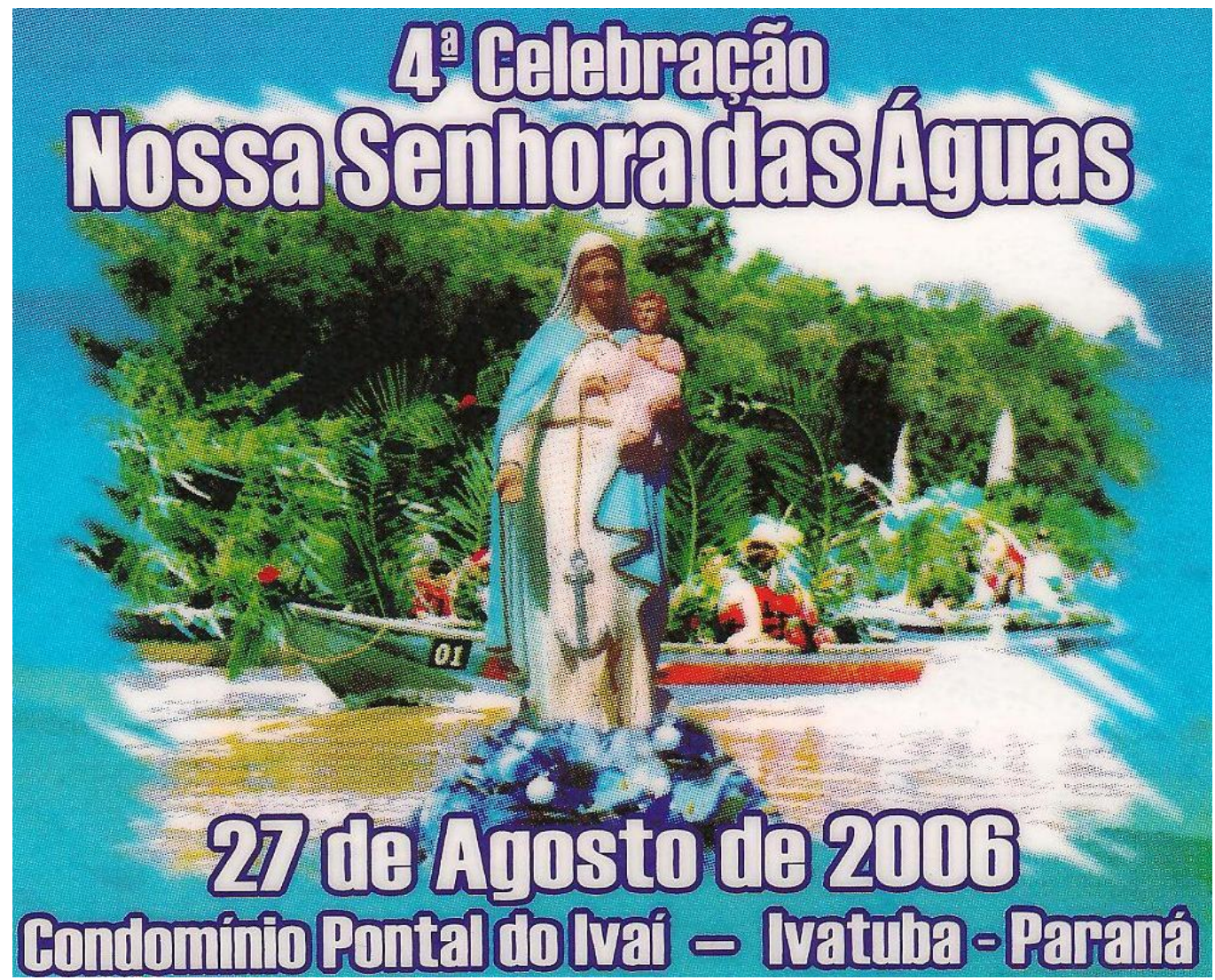

Fonte: Acervo João Evangelista Gimenes, 2006.

\footnotetext{
${ }^{12}$ Segundo o Pe. Jair Favoretto, a Campanha da Fraternidade realizada sempre no período da quaresma tem como objetivo despertar a solidariedade dos seus fiéis e da sociedade em relação a um problema concreto que envolve a sociedade brasileira, buscando caminhos para sua solução.
} 
A Imagem 3 reproduz o adesivo confeccionado no ano de 2006, nele são informados a data e o local da celebração. O decalque apresenta, no primeiro plano, a imagem de Nossa Senhora das Águas e ao fundo são ostentados símbolos intrínsecos a sua história, tais como pescadores, o rio Ivaí e a flora ivatubense.

Edilece Souza Couto (2004) atesta que na iconografia mariana, a imagem de Maria se apresenta em distintas posições do corpo e cortes das vestes. Carregando ou não o descendente de Deus nos braços e envolta de objetos variados. Na escultura de Nossa Senhora das Águas, a âncora, símbolo dos pescadores e navegadores se encontra nas mãos do Menino Jesus bem próxima do seu coração.

A vestimenta da Santa do Ivaí, possui tons azuis e branco em todo corpo, uma alusão à pureza da água encontrada nos poços artesianos do rio Ivaí, mencionada regularmente nas celebrações em louvor a Santa. O branco também pode ser associado à ideia de paz, de calma, de pureza e limpeza. Já o azul, cor do céu e do espírito, simboliza a lealdade, a fidelidade, a personalidade e subtileza, atribuídos na imagem da Virgem Maria.

Couto (2004) revela que essas vestimentas são encontradas também em outras imagens da mãe de jesus. A historiadora afirma que, normalmente, a Virgem utiliza uma túnica branca, um manto azul e traz na cabeça a coroa real. Nas imagens presentes nas igrejas é habitual encontrar a Rainha sobre o planeta Terra amarfanhando uma serpente, ícone do pecado original e da visão dualista do sexo feminino: mãe bondosa e acolhedora e, ao mesmo tempo, maligna e tentadora. Para Couto (2004), nas representações dos cultos populares o animal está vivo, circundando a terra ou enrolada no corpo da estátua. Assim a cobra pode ter outro significado: o de simbolizar a procriação, a fertilidade presente nos antigos cultos agrários. Sob os seus pés podem aparecer uma lua em fase crescente e cabeças de anjos.

No caso de Nossa Senhora das Águas a imagem é adornada com elementos da flora local, na festa em seu louvor, a Santa ficava exposta no lado direito do altar, enfeitada com fitas e sob vários balões azuis e brancos que formavam um semicírculo ou arco A imagem ficava no centro desse arco e sobre uma espécie de altar, construído para a virgem, onde brotava uma singela "cascata". Nossa Senhora ficava à frente da queda d'água.

Desse modo, os organizadores recriavam o mito fundador dessa Santa, responsável por conceder um bem maior aos seus "filhos", o" bem potável" sem o qual não existiria vida. Velas eram acesas diante dela, do lado direito e esquerdo uma vez 
que elas simbolizavam a luz, a direção a seguir. Na Imagem 4, podemos verificar mais detalhadamente os adornos supracitados.

\section{Imagem 4 - Altar de Nossa Senhora das Águas, 2005}

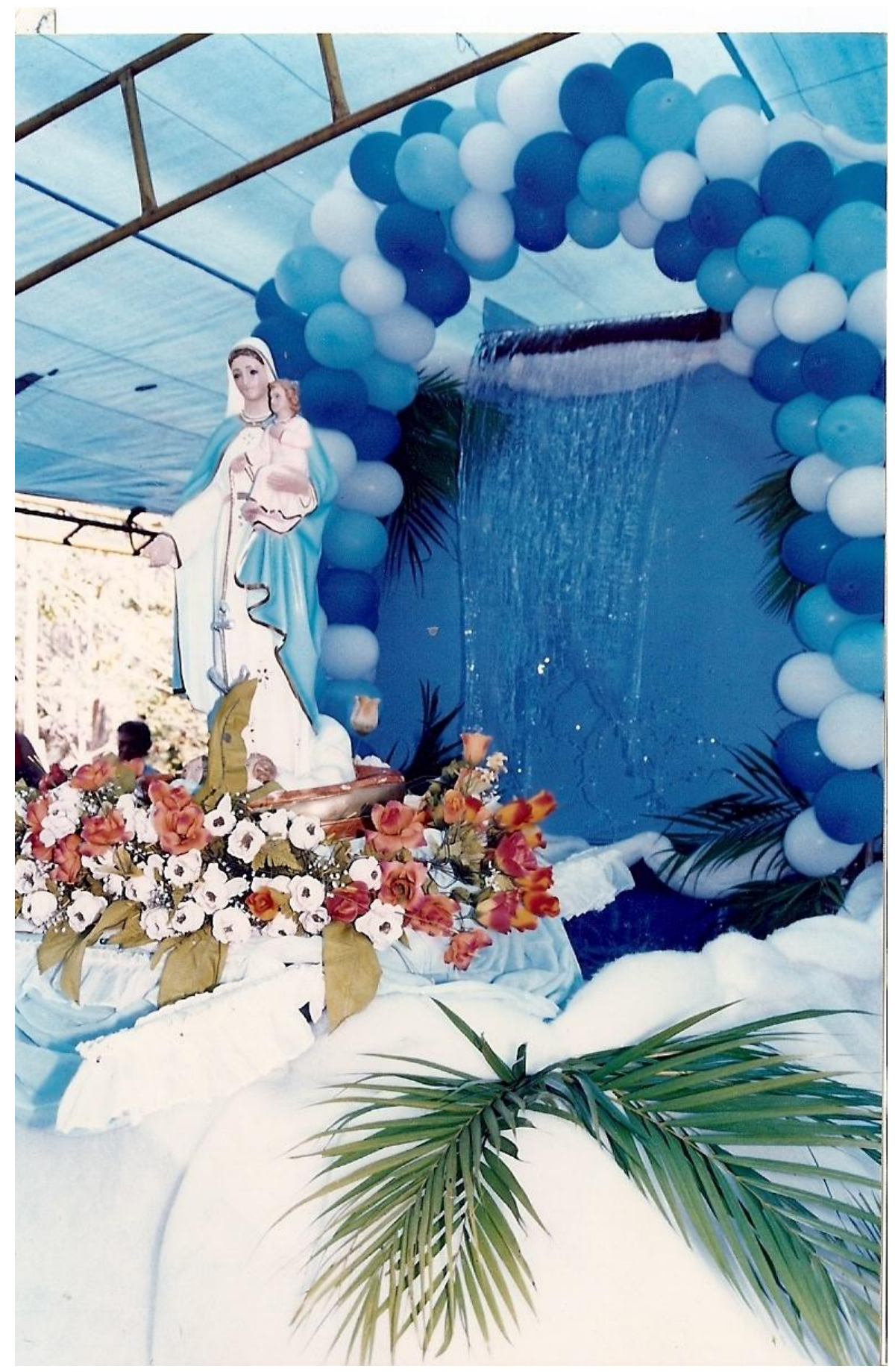

Fonte: Acervo Anísio Furlan. 
Nesta imagem, o fotógrafo, apesar de optar por um enquadramento vertical e provocar a concentração das linhas de visão, procurou inserir em um mesmo quadro a Santa, as rosas, folhas de coqueiros e a referida "cascata". Cumpre atentar, que como qualquer outra fonte, a fotografia deve ser questionada, analisada e confrontada. Nesta pesquisa entende-se que, para o historiador, “[...] utilizar a evidência de imagens de forma segura, e de modo eficaz, é necessário como no caso de outros tipos de fonte, estar consciente das suas fragilidades" (BURKE, 2004, p. 18).

Fundamentalmente, é preciso considerar que ela em si não é neutra: a fotografia fala, tem um discurso que deve ser visto e revisto dentro de um contexto em que foi produzida. Conforme aponta Burke (2004), as imagens interessam ao historiador, tanto pelo que deixam transparecer quanto ao que omitem. No caso da imagem 4 os adereços em volta da Santa reforçam a mensagem de que a Nossa Senhora das Águas atua como protetora dos bens naturais.

Esse apego por imagens e simbolos nas celebrações religiosas, tem suas raizes fundadas no século XVI. No Brasil, o catolicismo ibérico que desembarcava na região, no século XVI, foi hegemonicamente devocional e iconófilo. Segundo Mauricio de Aquino (2011), os primeiros europeus responsáveis pela cristianização no continente sulamericano carregavam consigo inúmeras imagens de santos, principalmente, as da Virgem Maria.

O historiador expõe que o catolicismo português era essencialmente mariano, e o apreço pelos retratos e fíguras consolidou-se após as batalhas da reconquista da penísula, transformando-se em um marco da identidade ibérica. Nesse contexto, Maria tornava-se, também, o símbolo da identidade católica na guerra contra os reformistas protestantes, nas vitórias sobre os mouros, na descoberta do caminho das Indias e na restauração da independência portuguesa, na primeira metade do século XVII.

De acordo com Nilza Botelho Megabale (2001), os lusitanos transmitiram essa devoção ao culto mariano e a difundiram em solo brasileiro:

\footnotetext{
Várias efigeis da Mãe de Deus chegaram ao nosso país, trazidas por marinheiros ou colonizadores lusitanos, que espalharam o culto das invocações em moda ou das padroeiras de suas províncias ou cidades natais. Alem da Senhora da Esperança que veio na nau de Pedro Álvares Cabral e da Senhora da Glória, que consta ter chegado à Terra de Santa Cruz em 1503, muitas outras como as do Ó, do Monte, da Luz, da Graça, da escada, ornamentaram os altares dos mais antigos tempos coloniais (MEGABALE, 2001, p. 17).
} 
Atentamos para a festa de Nossa Senhora das Águas. No ano de 2002, apoiados pela prefeitura municipal de Ivatuba e pelos condôminos, foi realizada a primeira festa ${ }^{13}$ em louvor a Rainha das Águas, dividida nas seguintes etapas: desfile fluvial, recepção a Nossa Senhora, missa eucarística e, por último, confraternização e almoço com os devotos. Em 2004, a convite do Pe. Jair Favoretto, do arcebispo Dom Jaime Luiz Coelho presidiou a celebração e instituiu a Santa como a Padroeira do rio Ivaí.

A ocasião tornou-se importante para a consolidação da sacralização da Festa de Nossa Senhora das Águas na região, pois Ela deixou o seu perfil restrito ao município e expandiu-se como símbolo de fé regional tornando-se rapidamente a padroeira de todas as cidades banhadas pelo rio Ivaí. Além disso, a presença do arcebispo acabou por legitimar a relação de fé e devoção da santa perante a população. Uma vez que Dom Jaime Luís Coelho, era respeitado na região.

Segunda Claudete Ghelere ${ }^{14}$, as missas que contavam com a participação do arcebispo eram sempre as mais numerosas pois a homilia de Dom Jaime, era admirada pela comunidade católica. No ano de 2004, durante a celebração da Santa do Ivaí, ao legitimar a Virgem da Águas como a Protetora dos bens naturais, nascida nas margens do Rio Ivaí, a santa passou a exercer o papel de não apenas a padroeira do Ivaí mas também a protetora do meio ambiente ${ }^{15}$.

Dentro do catolicismo popular, Maria possui diversas representações e vários significados construídos e apropriados conforme o espaço, causa ou circunstância, no caso de Nossa Senhora das Águas, temos como espaço o local que teria sido "amaldiçoado" pelo padre, a causa seria a busca pela água para abastecer toda aquela região e as circunstancias seriam justamente a falta de água que comprometeria o término das obras do condomínio Pontal do Ivaí.

Enquanto para a Igreja, Maria é a Nossa Senhora, para o povo ela é singelamente a Senhora, a Mãe. De índole dogmática para os fiéis a Virgem é considerada uma criatura privilegiada pelas prerrogativas que Deus lhe concedeu. Algumas nomeações recebem determinados termos em função de um fenômeno ou acontecimento "fantástico" que permeia a aparição da Virgem. Ela teria estabelecido

\footnotetext{
${ }^{13}$ A organização do loteamento instituiu o último domingo de agosto como data comemorativa a Nossa Senhora das Águas, pois nesse dia era celebrada a Assunção da Virgem ao céu.

${ }^{14}$ Claudete Ghelere. Entrevistado por João Paulo Pacheco Rodrigues, 4 abr. 2011.

${ }^{15}$ Essa nova dimensão da santa é atestada no primeiro rito da missa em louvor a Virgem, na qual a cerimônia iniciava-se com o Hino Nacional.
} 
contato com os devotos tendo em vista "alertar seus filhos" que no caso de Nossa Senhora das Águas seria em relação a preservação do meio ambiente.

Na celebração do ano de 2005 o então prefeito Adolfo Semprebom ressaltou a importância da Santa para comunidade local, referenciando a festa como uma "tradição" do município. Para ele, os ivatubenses se identificavam e veneravam a Virgem por ela ter nascido no seio da sociedade católica da região.

Vale lembrar que Erick Hobsbawn (1984) afirma que algumas tradições, por mais que pareçam ser antigas, foram inventadas em curto espaço de tempo. Assim, o historiador define o termo "tradição inventada" como um complexo de práticas geralmente reguladas por normas subentendidas ou claramente aceitas. Essas práticas de ordem ritual ou simbólica tendem a firmar certos valores e normas de comportamentos pela repetição, o que resultaria numa continuidade de um passado histórico apropriado. Por essa via, o autor argumenta que a invenção da tradição ocorre com mais frequência quando uma transformação rápida da sociedade aniquila os padrões sociais para quais as tradições foram feitas, produzindo novos modelos (HOBSBAWN, 1984).

Para o historiador Hobsbawm (1984), a construção dos símbolos é um dos fatores que ajuda na agregação das tradições inventadas por parte das sociedades. A utilização de elementos antigos destes povos, aliadas a uma linguagem elaborada e compostas de práticas e comunicações simbólicas religiosas, tendem a ser associadas aos problemas presentes no seu cotidiano.

Por conseguinte, o processo de criação e invenção das tradições pode estar estreitamente relacionado com tradições já conhecidas. As novas tradições se apegam aos ritos e ações já conhecidas. Um exemplo claro é o objeto desse estudo: parte significativa do festejo é similar aos ritos da celebração em louvor a Nossa Senhora dos Navegantes. No caso da festa realizada no condomínio Pontal do Ivaí, ocorreu uma adaptação e a reutilização do cerimonial da Virgem dos Navegantes, aliás, essa mudança parece ter sido fundamental para que a população de Ivatuba se identificasse com a comemoração.

Em 2005, o Governo do Paraná e a Secretaria de Estado da Cultura registraram a celebração de Nossa Senhora das Águas no livro "Festas Populares do Paraná", de autoria de Renato Augusto Junior Carneiro - fundamental para o reconhecimento cultural que a festa vem adquirindo. Entretanto, três anos depois, em 2008, a festa passou por profundas transformações, principalmente porque o espaço do condomínio não suportava aumento do número de romeiros, que já passava dos 3 mil participantes. 
A partir de então, a celebração passou a ser realizada no perímetro urbano de Ivatuba, sem que o desfile fluvial, às margens do rio Ivaí, deixasse de existir. Somente os festejos, as barracas e o ato litúrgico da missa foram transferidos para o perímetro urbano da cidade. A mudança do local foi justificada por duas questões: primeira, o salão paroquial da Igreja Nossa Senhora do Rocio era extenso, capaz de receber o contingente de devotos, e segunda, número de reclamações dos proprietários dos lotes e casas do condomínio crescia a cada edição da festa e eles alegavam que o espaço reservado ao sossego, descanso e lazer tornava-se uma "bagunça", pessoas estranhas acabavam tendo acesso ao local e muito lixo era produzido.

Anísio Furlan recorda que as reclamações eram originária de dois grupos: os condôminos que não eram católicos, e aqueles que não concordavam com a maneira em que a Santa era cultuada. Esses alegavam que a Virgem do Ivaí não seria uma santa como Nossa Senhora Aparecida, a padroeira do Brasil ou Nossa Senhora de Guadalupe, padroeira do México. Para essa ala, o fato do padre ter criado uma nova santa, soava como um tanto oportunismo, uma vez que o número de devotos que seguiam Favoretto aumentou consideravelmente. Outro fator que chamava atenção dos reacionários a festa, era a de que o padre sempre estava acompanhado de políticos como deputados estaduais, prefeitos, vereadores e assessores de gabinetes.

Nas celebrações, esses políticos eram chamados a subir no palco e Favoretto tecia elogios as figuras públicas, como se eles fossem os responsáveis pela execução da festa, fato que atesta o caráter político que a celebração passou a exercer na última década.

Para Maria Vanso ${ }^{16}$, moradora do de Ivatuba e participante da festa, "o fato da Santa ter sido criada não é algo que segrega a festa, pois Maria é única, ela é a mesma em todos os lugares, o que diferencia é a urgência e a causa em que ela apareceu e nós ivatubense temos que nos orgulhar de ter uma Santa só nossa, ela veio para nos alertar que o homem está acabando com o meio ambiente está acabando”. A devota Mercê de Matia, destaca que "a Virgem Maria só aparece quando alguma coisa não está certa, foi assim em Portugal com a Nossa Senhora de Fatima que apareceu para as crianças e agora é aqui em Ivatuba. O rio Ivaí está sendo poluído, é muito lixo que jogamos e Maria está chamando a nossa atenção para essa causa",17

\footnotetext{
${ }^{16}$ Maria Vanso. Entrevistado por João Paulo Pacheco Rodrigues, 8 fev. 2012.

${ }^{17}$ Mercê de Matia. Entrevistado por João Paulo Pacheco Rodrigues, 14 mar. 2012
} 
O depoimento de Maria Vanso e Mercê Matia, revelam o sentimento de pertença e identidade construídos em pouco tempo entre os moradores da região Santa. Os impasses individuais "resolvidos" com a mediação da santa geraram uma identidade religiosa que culminou em um projeto mais complexo: a luta em prol da preservação das águas do rio Ivaí e da diversidade da flora local. Mesmo que essa "causa" tenha sido sugerida pelos mentores da celebração, ela foi aceita e acolhida pela comunidade. No dia 9 de julho de 2012, foi promulgado a Lei 17.613, que estabeleceu Nossa Senhora das Águas como Padroeira do Rio Ivaí.

\section{Considerações finais}

Esse artigo teve como objetivo a compreensão da construção mítica em torno da Santa do Ivaí. Radicada no cerne da comunidade católica de Ivatuba, a crença na Virgem manteve uma linha tênue entre a devoção religiosa e o medo do desconhecido. A premonição de um padre, convicto de que o lado sul de Ivatuba não iria se desenvolver cobriu esse espaço de uma áurea mística, mas, por circunstâncias ora investigadas, o referido lugar foi cenário da manifestação da Virgem. Além disso, acontecimentos como a decadência da cultura do café, o advento da lavoura branca, a morte da jovem no antigo porto de areia e o encontro da estatueta de uma santa sem cabeça no Pontal sustentaram os alicerces e fizeram crescer a crença nos milagres de Nossa Senhora das Águas.

Algumas particularidades relativas ao fomento da religiosidade no município contribuíram para que a devoção a ela se difundisse rapidamente. A mesma comunidade que adotou São Sebastião como seu protetor desde que se instalou na região abraçou as "causas" atribuídas a Rainha do Ivaí. Em ambos os casos a crença em Nossa Senhora do Rocio teria sido deixada em um plano secundário?

Esta indagação torna necessária a retomada de pistas investigadas na primeira parte desse artigo. De certa forma, os migrantes foram obrigados a aceitar Nossa Senhora do Rocio como padroeira da cidade por imposição do Arcebispo Dom Jaime, uma vez que cultuava o Santo de Milão e alimentava a crença de que Ele teria resguardado a todos e dado forças para a comunidade enfrentar as agruras do desmatamento, as doenças e o temor da instalação em terras desconhecidas. As demonstrações de fé em São Sebastião se expressavam nas novenas, festas e procissões, 
muitas delas registradas em fotografias - aspecto que confere aos eventos referidos maior solenidade e a importância de serem registrados para a posteridade.

Posteriormente, a veneração a Nossa Senhora das Águas foi justificada pelo fato de que Ela teria suplantado o "mal", na medida em que demonstrou seu poder em um espaço tido como "amaldiçoado" durante muitos anos. Legitimada pela mesma autoridade eclesiástica de outrora (D. Jaime), a figura de Nossa Senhora das Águas foi alijada a uma causa coletiva considerada crucial na atualidade, qual seja a proteção dos bens naturais

Os documentos levantados não deixam dúvida de que o "milagre da água" concorreu para transformar o Condomínio Pontal do Ivaí em um empreendimento promissor. O Sr. Anísio Furlan, idealizador do loteamento, não dissimula que a valorização dos lotes naquela região ocorreram em decorrência do sucesso das festividades em louvor a Nossa Senhora das Águas, pois, além de retirar o estigma negativo sobre o local, o tornou mais conhecido. Os primeiros terrenos, vendidos no ano de 1997, valiam cerca de sete ou oito mil reais (dependendo da localização), atualmente os poucos lotes que ainda restam sofreram uma valorização de aproximadamente $1.200 \%$, estão sendo negociados por cento e vinte mil reais

Torna-se capital salientar que os indícios levantados no decorrer dessa pesquisa permitiram inferir que mesmo se a decisão de legitimá-la como padroeira do rio não fosse posta pelo Padre Jair Favoretto e ratificada pelo Arcebispo Dom Jaime Luiz Coelho, a santa não sofreria resistência por parte das comunidades católicas daquela região, porque os fiéis tomaram a manifestação da Virgem como um sinal divino.

As relações de dádiva e contradádivas se complementaram, portanto, na perspectiva dos fiéis, os milagres se concretizaram. Assim, ano após ano, a devoção foi adquirindo um colorido cada vez maior no universo fantástico recriado pelos devotos que continuaram a participar das celebrações, apesar das celeumas entre os padres e das dificuldades de adequação dos espaços.

A popularidade da festa foi atestada no livro "Festas Populares do Paraná" (CARNEIRO, 2005, p. 67), algo singular do ponto de vista a formalização de seu reconhecimento como um bem imaterial. Não ao acaso, o governo estadual tomou a iniciativa de listar as várias tipologias patrimoniais do Estado. O reconhecimento dos bens culturais imateriais constituiu uma demanda desde as proposições da Constituição de 1988, fortalecidas pela oficialização das primeiras manifestações populares, como o grafismo indígena, as festas de tambor, os saberes de ofício, entre outros. 
A história da Virgem das Águas se assemelha a tantas outras narradas no território nacional. No Brasil, a Virgem Maria possui diversas representações do ponto de vista dos católicos e Igreja Católica Romana, mas, talvez a mais significativa delas tenha sido a de universalizar a devoção à mãe do filho de Deus, Jesus Cristo. 


\section{REFERÊNCIAS}

ADUCCI, Edésia. Maria e seus títulos gloriosos. São Paulo: Loiola, 1998.

AQUINO, Maurício de. História e Devoção. Bauru: Editora USC, 2011.

BÍBLIA SAGRADA. Edição Pastoral, São Paulo: Paulus, 2004.

BURKE, Peter. Testemunha ocular: história e imagem. Bauru: EDUSC, 2004.

CARNEIRO JUNIOR, Renato Augusto. Festas populares do Paraná. n. 2. Curitiba: Secretaria de Estado da Cultura, 2005.

CHARTIER, Roger. À Beira da falésia: a história entre incertezas e inquietudes. Trad. Patrícia Chittoni Ramos. Porto Alegre: UFRGS, 2002.

COUTO, Edilece Souza. Tempo de festas: homenagens a Santa Bárbara, N. S. da Conceição e Sant'Ana em Salvador (1860 - 1940). 2004. Tese (Doutorado em História) - Universidade Estadual Paulista Júlio de Mesquita Filho, Programa de Pós-Graduação em História, São Paulo, 2004.

DA MATTA, Roberto. O que faz o Brasil, Brasil? 7. ed. Rio de Janeiro: Rocco, 1994.

DESTEFAnI, E. V. Regime Hidrológico do Rio Ivaí - PR. 2005. 94 f. Dissertação (Mestrado em Geografia) - Universidade Estadual de Maringá, Programa de PósGraduação em Geografia, Maringá, 2005.

HOBSBAWM, Eric. Introdução: a invenção das tradições. In: HOBSBAWM, Eric; RANGER, Terence (Org.). A invenção das tradições. Rio de Janeiro: Paz e Terra, 1984. p. 9-23.

LE GOFF, Jacques. Memória. In: LE GOFF, Jacques. História e Memória. 5a Campinas: Ed. Unicamp, 2003.

LICHT, Henrique. Nossa Senhora dos Navegantes: Porto Alegre 1871-2006. Porto Alegre: Editora Polotti, 2008.

MAGABALE, Nilza Botelho. Invocações da Virgem Maria no Brasil. Petrópolis/RJ: Vozes, 2001.

MOTA, Lucio Tadeu. História do Paraná: ocupação humana e relações interculturais. Maringá: EDUEM, 2005.

PELEGRINI, Sandra. Patrimônio Cultural: consciência e preservação. São Paulo; Brasiliense, 2009.

PELEGRINI, Sandra; RODRIGUES, João. Ivatuba: história, memória e tradição paranaense. Maringá: Unicorpore, 2014. 
PETRUSKI, Maura Regina. Julho chegou... E a festa também: Sant'ana e suas comemorações na cidade de Ponta Grossa (1930-1961). 2008. 267 f. Tese (Doutorado em História) - Universidade Federal do Paraná, Programa de Pós-Graduação em História, Curitiba, 2008.

PORTELLI, Alessandro. O momento da minha vida: funções do tempo na história oral. In: FENELON, Déa et al. (Org.). Muitas memórias, outras histórias. São Paulo: Olho d'Água, 2004. p. 298-313. 